\title{
Performance Evaluation of Chickpea Varieties (Cicer arietinum L.) at Bule Hora and Abaya Southern Ethiopia
}

Ejigu Ejara (Corresponding Author)

Yabello Pastoral and Dryland Agriculture Research Centre, Oromia Agricultural Research Institute, Yabello, Ethiopia Email: ehordofa@gmail.com

\section{Kemal Kitaba}

Yabello Pastoral and Dryland Agriculture Research Centre, Oromia Agricultural Research Institute, Yabello, Ethiopia

\section{Zinash Misganaa}

Yabello Pastoral and Dryland Agriculture Research Centre, Oromia Agricultural Research Institute, Yabello, Ethiopia

\section{Ganene Tesama}

Yabello Pastoral and Dryland Agriculture Research Centre, Oromia Agricultural Research Institute, Yabello, Ethiopia

\author{
Article History \\ Received: April 7, 2020 \\ Revised: May 2, 2020 \\ Accepted: May 9, 2020 \\ Published: May 12, 2020 \\ Copyright (C) 2020 ARPG \\ \& Author \\ This work is licensed \\ under the Creative \\ Commons Attribution \\ International \\ (c) (1) $C C$
}

BY: Creative Commons Attribution License 4.0

\begin{abstract}
Chickpea is among the major pulse crops grown in southern Ethiopia including Borana and West guji zone. The area has potential to the production of Chickpea for food and nutrition security as well as export commodity. However, scarcity of varieties that fit to the environment is one of the major constraints of production. Therefore, this experiment was conducted to evaluate 9 chickpea varieties to select adaptable varieties for yield and agronomic traits. The field experiment was conducted in 2017 and 2018 at two locations (Abaya and Bule hora) and varieties were planted in Randomized complete block design. Data were collected on yield and important agronomic traits. Analysis of variance computed for individual locations and combined analysis over locations revealed significant variations among varieties. Moreover, Varieties showed a grain yield as high as $1087.5 \mathrm{~kg} / \mathrm{ha}$ and $873.79 \mathrm{~kg} / \mathrm{ha}$ at Bule hora and Abaya respectively. Minjar variety is significantly high yielding variety at both locations with yield advantage of $26.13 \%$ and $52.07 \%$ over variety mean at Bule hora and Abaya respectively and therefore recommended for both locations and locations with similar agro ecologies.
\end{abstract}

Keywords: Adaptability; Mean grain yield; Yield related traits.

\section{Introduction}

Chickpea (Cicer arietinum L.) is a diploid species with $2 \mathrm{n}=16$ chromosomes. It is a self-pollinated crop, with natural cross-pollination of up to one per cent [1]. Chickpea is among the oldest crops, being domesticated in the Fertile Crescent 10,000 years ago [2] and named as Bengal gram (Indian), Chickpea (English), Garbanzo (Latin America), Hommes, Hamaz (Arab world), Nohud, Lablabi (Turkey), Shimbra (Ethiopia). It is the lone domesticated species among the 44 species comprising 33 perennial and eight annual wild species and highly preferred pulse for human consumption within the genus Cicer [3], family Fabaceae, tribe Cicerae. Chickpea is grown in tropical, subtropical and temperate regions. It is a valued crop and provides nutritious food for an expanding world population and will become increasingly important with climate change [4]. Chickpea contains nutritive seeds with high protein content, 25.3-28.9\%, after dehulling [5], 38-59\% carbohydrate, 3\% fiber, 4.8-5.5\% oil, 3\% ash, $0.2 \%$ calcium, and $0.3 \%$ phosphorus. Digestibility of protein varies from $76-78 \%$ and its carbohydrate from $57-60 \%$ [5]. Chickpea seeds are eaten fresh as green vegetables, parched, fried, roasted, and boiled; as snack food, sweet and condiments; seeds are ground and the flour can be used as soup, dhal, and to make bread; prepared with pepper, salt and lemon it is served as a side dish [6]. Chickpea is beneficial to a healthy diet. For example a half-cup serving provides $7 \mathrm{~g}$ of protein (10\% of our daily requirement) and $6 \mathrm{~g}$ of fiber (20\% of our daily requirement) [7]. It plays a significant role in improving soil fertility by fixing the atmospheric nitrogen. It can fix up to $140 \mathrm{~kg} \mathrm{~N}$ ha-1 from air and meet most of its nitrogen requirement [8].

According to Central Statistical Agency [9] in Ethiopia, Pulse crops production ranks second in terms of production area. Pulses grown in Ethiopia covered $12.33 \%$ (1,549,911.86 hectares) of the grain crop area and 9.69\% (about 28,146,331.73 quintals) of the grain production. In Ethiopia, chickpea is mainly grown in the central, northern and eastern highland areas of the country at an altitude of 1400-2300 m.a.s.l., where annual rainfall ranges between 700 and $2000 \mathrm{~mm}[10,11] . \%$. It is best adapted to the areas having Vertisols [8].

Chickpea production has increased from 60085 tons (1993) to 473570 tons (2017). The production areas are also increased from 109750 hectare (1993) to 473570 hectare (2017) [12]. 


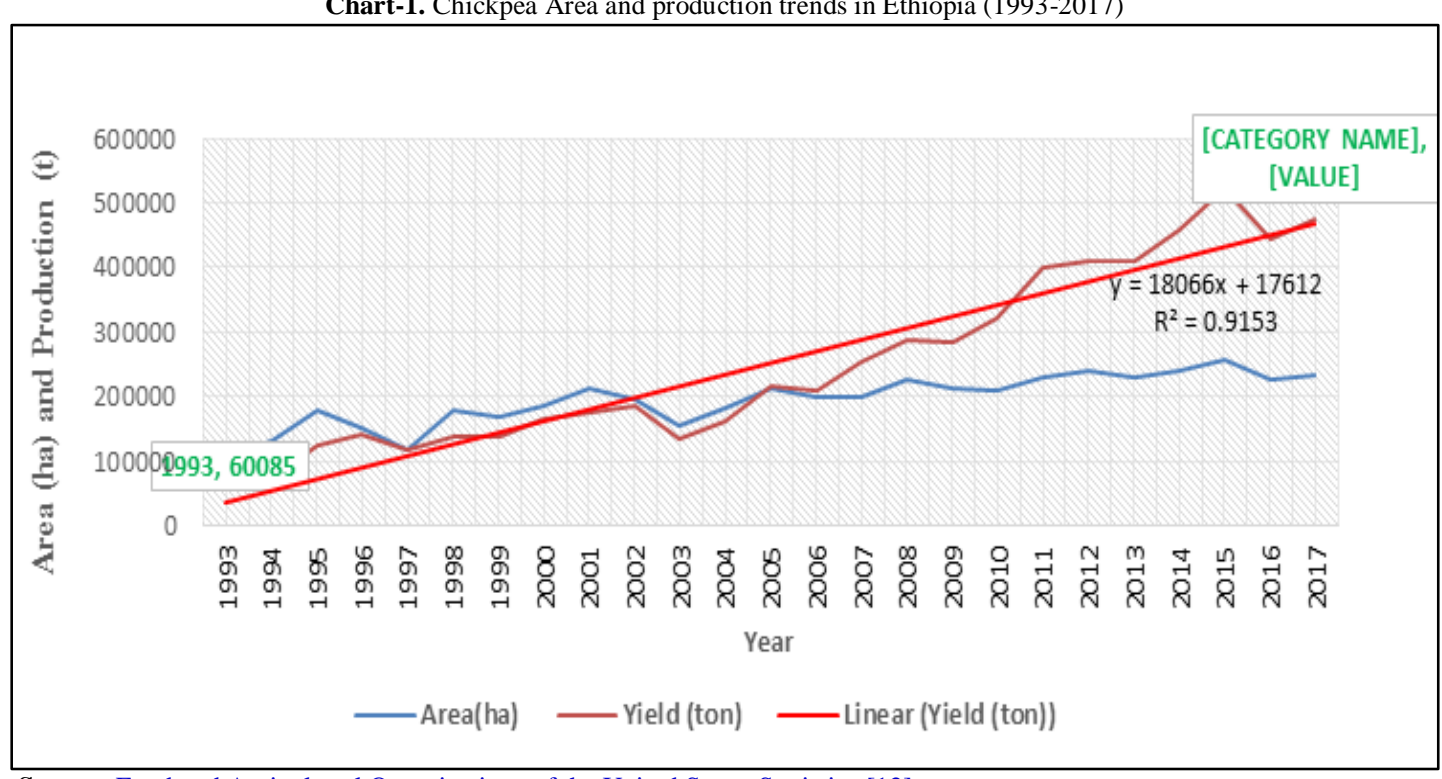

Source: Food and Agricultural Organizations of the United States Statistics [12]

In the study areas, shortage of chickpea varieties that adapt to the prevailing environments are the top chickpea production constraints. Therefore, this study was incited with the objective to test the adaptability of chickpea varieties for yield and yield related traits in the study areas.

\section{Materials and Methods}

\subsection{Site Description}

The experiment was conducted at Bule hora and Abaya during 2017 and 2018 cropping season. The experimental areas are located in the Southern part of the country in the Oromia Regional State. Bule hora and Abaya are located at 465 and $365 \mathrm{~km}$ far from Addis Ababa city, respectively.

\subsection{Experimental Materials}

For this study, 9 released Chickpea varieties were obtained from Debrazayit Agriculture Research Centre (DzARC) and evaluated for adaptability of the varieties

Table-1. Released Chickpea varieties use in the experiment

\begin{tabular}{l|l|l|l}
\hline S.No & Variety & Year of release & Breeding center \\
\hline 1 & Dhera & 2016 & DZARC \\
\hline 2 & Arerti & 1999 & DZARC \\
\hline 3 & Hora & 2016 & DZARC \\
\hline 4 & Ejeri & 2005 & DZARC \\
\hline 5 & Habru & 2004 & DZARC \\
\hline 6 & Natoli & 2007 & DZARC \\
\hline 7 & Minjar & 2010 & DZARC \\
\hline 8 & Dalota & 2013 & DZARC \\
\hline 9 & Dimtu & 2016 & DZARC \\
\hline
\end{tabular}

\subsection{Experimental Design and Managements}

The experiment was laid out in Randomized Complete Block Design. Each entry was planted in a plot having 6 rows of 3 meter length. Four rows were harvested and two border rows were left to exclude border effect. The row and plant spacing was kept at $40 \mathrm{~cm}$ and $10 \mathrm{~cm}$, respectively. Individual plot size was $2.4 \mathrm{~m} \mathrm{x} 3 \mathrm{~m}=7.2 \mathrm{~m}^{2}$ and $1 \mathrm{~m}$ and $1.5 \mathrm{~m}$ between plot and block, respectively. $60 \mathrm{~kg}$ NPS/ha Fertilizer was applied at the time of planting. All other agronomic managements were applied uniformly in all experimental plots as per national recommendation for the crop.

\subsection{Data Collection}

The following data were collected during the experiment time both from the whole plot, net plot and sampled plants by random selection method from the middle of four rows of each plot.

\subsection{Data Recorded on Plant Basis}

Plant height at harvest $(\mathrm{cm})$ : Height of five randomly taken plants during harvest period from each experimental plot was measured in centimeter from the ground level to top of the plants and the average height was recorded. 
Number of primary branches: Number of productive branches extending from the main stem was recorded from five randomly selected plants and average branch number was taken.

Pod length $(\mathrm{cm})$ : The length of five randomly selected pods from each of the five randomly selected plants was measured at harvesting and the average was used.

Number of pods per plant: this was recorded as average total number of pods of five randomly selected plants from each experimental plot at harvest.

Number of seeds per pod: This was recorded as average total number of seeds of five randomly selected plants from each experimental plot divided by total number of pod of the same plants at harvest.

Seeds per plant: Average number of seeds counted from five randomly selected plants.

\subsection{Data Collection on Plot Basis}

Days to Flowering: The numbers of days from the date of emergence to the date on which about $50 \%$ of the plants in each plot produce flowers.

Days to maturity: The number of days from planting to the date when $90 \%$ of the morphological observation of the plant turned to yellow straw colour.

Stand count at harvest: This was recorded by counting the total number of plants from the four middle rows of each plot at harvest.

Grain yield (g/plot): Grain yield in grams obtained from the central four harvestable rows of each plot was harvested, threshed and weighted using sensitive balance.

Grain yield (ton/ha): Grain yield obtained from each plot was used to estimate grain yield (tons) per hectare.

\subsection{Data Analysis}

\subsubsection{Analysis of Variance}

Analysis of variance (ANOVA) was computed for grain yield and other traits as per the methods described by Gomez and Gomez [13] using SAS computer software (Version 9) for Randomized Complete Block Design. Comparison of treatment means was made using Duncan Multiple Range test (DMRT) at 5\% level of significance. Location wise analyses were performed and error variances were subjected to F-test for homogeneity test of variances. Variables with homogeneous error variances were directly used for combined analyses, while those with heterogeneous error variances were analyzed in individual locations. The combined analysis was based on mixed model (fixed genotype and random environment).

Individual locations and combined ANOVA were computed using the following mathematical model:

Individual locations ANOVA model

Where, $X i j k l=$ Observed value,

$$
X i j k l=\mu+G i+B j k+Y+G Y i+E i j k
$$

$\mu=$ general mean,

$G i=$ effect of variety,

$B j k=$ effect of replication (block),

$Y=$ effect of year,

$G Y i=$ variety $\mathrm{x}$ Year,

$E i j k$ = residual effects or experimental error. Additionally, g, r, y are numbers of geneotypes, replications, locations and years, respectively

\subsubsection{Combined ANOVA Model}

$$
X i j k l=\mu+G i+B j k l+L k+Y l+G L i k+G Y i l+L Y k l+G L Y i k l+E i j k l
$$

Where, $X i j k l=$ Observed value,

$\mu=$ general mean,

$G i=$ effect of genotype,

$B j k l=$ effect of replication (block),

$L k=$ effect of location,

$Y l=$ effect of year,

$G L i k+G Y i l+L Y k l+G L Y i k l=$ effects of Genotype $\mathrm{x}$ Location, Genotype $\mathrm{x}$ Year, Location $\mathrm{x}$ Year, and Genotype $\mathrm{x}$ Location $\mathrm{x}$ Year interactions, respectively.

Eijkl = residual effects or experimental error. Additionally, $g, r, l, y$ are numbers of geneotypes, replications, locations and years, respectively.

\section{Results and Discussion}

\subsection{Analysis of Variance}

The experiment was conducted at two locations viz. Bule hora and Abaya. Homogeneity of variance was computed for each location before the combined analysis of variance computed. The analysis of variance were computed for days to flowering, days to maturity, plant height, number of primary branches, pods per plant, seeds per pod, seeds per plant and grain yield per hectare. The individual location and the combined analysis of variance results are presented in subsequent sections. 


\subsection{Individual Location Analysis of Variance}

Analysis of variance computed for each location revealed that variation among varieties were highly significant $(\mathrm{P}<0.01)$ for all traits at both locations except seeds per pods are significant $(\mathrm{P}<0.05)$ at Bule hora and not significant at Abaya (Table 2 and Table 4). The presence of variations among varieties under experiment for all the traits studied indicated the presence of sufficient variability among Chickpea varieties that would be exploited through selection. The year effect was highly significant $(\mathrm{P}<0.01)$ at both location, indicated that the performance of varieties are different in different locations. Ercan, et al. [14], also reported different performance of Chickpea genotypes in different year and location.

In Ethiopia, Getachew, et al. [15] reported the presence of highly significant variation among 17 Kabuli type Chickpea genotypes conducted in five environments. He also reported the existence of significant variation for days to flowering, days to maturity, plant height, pods per plant, seed per pod, 100 seed weight and Grain yield. Ercan, et al. [14], Rozina, et al. [16], Dan, et al. [17] and Desai, et al. [18] also reported highly significant variation for plant height, pods per plant, seeds per plant, hundred seed weight and grain yield in Chickpea which is in line with this finding.

Table-2. Mean squares from combined analyses of variance over two years for 8 traits of Chickpea varieties grown at Bule hora in 2010 and 2011 E.C

\begin{tabular}{|c|c|c|c|c|c|c|c|c|c|}
\hline $\begin{array}{l}\text { Source of } \\
\text { variation }\end{array}$ & df & GY (kg/ha) & FD & MD & PH (cm) & NPB & PPP & SPPnt & Spp \\
\hline Year $(Y)$ & 1 & $\begin{array}{l}9144171.941 \\
* * *\end{array}$ & $\begin{array}{l}200.296 \\
* * *\end{array}$ & $\begin{array}{l}852.04 \\
* * *\end{array}$ & $121.50 * *$ & $\begin{array}{l}12.907 \\
* * *\end{array}$ & $\begin{array}{l}4911.57 \\
4 * * *\end{array}$ & $\begin{array}{l}4907.760 \\
* * *\end{array}$ & 0.042 \\
\hline Variety (V) & 8 & $\begin{array}{l}221172.044 * \\
* *\end{array}$ & $\begin{array}{l}52.031 * \\
* *\end{array}$ & $\begin{array}{l}94.573 \\
* * *\end{array}$ & $\begin{array}{l}138.013 * \\
* *\end{array}$ & $\begin{array}{l}2.250 * \\
*\end{array}$ & $\begin{array}{l}238.270 \\
* *\end{array}$ & $\begin{array}{l}483.868 * \\
* *\end{array}$ & 0.055 \\
\hline $\begin{array}{l}\text { Reps.withn } \\
\text { (Y) }\end{array}$ & 4 & 12870.114 & 12.106 & $\begin{array}{l}28.764 \\
* *\end{array}$ & 17.484 & $\begin{array}{l}4.788 * \\
* *\end{array}$ & $\begin{array}{l}793.759 \\
*\end{array}$ & $\begin{array}{l}740.088 * \\
* *\end{array}$ & 0.023 \\
\hline $\mathrm{Y}^{*} \mathrm{~V}$ & 8 & $\begin{array}{l}75879.754 * * \\
*\end{array}$ & 6.369 & 5.781 & 13.613 & $\begin{array}{l}2.610 * \\
*\end{array}$ & 44.297 & 99.891 & 0.008 \\
\hline $\begin{array}{l}\text { Pooled } \\
\text { Error }\end{array}$ & 32 & 5575.47 & 6.553 & 5.493 & 11.188 & 0.627 & 69.045 & 80.962 & 0.031 \\
\hline $\mathrm{CV}(\%)$ & & 9.29 & 4.097 & 2.058 & 7.76 & 18.40 & 26.03 & 29.92 & 19.14 \\
\hline
\end{tabular}

ns, ***\&***,non-significant, significant at $\mathrm{P}<0.05, \mathrm{P}<0.01$ and $\mathrm{P}<0.001$, respectively. $\mathrm{DF}=$ degree of freedom, $\mathrm{FD}=$ days to flowering, $\mathrm{GY}(\mathrm{kg} / \mathrm{ha})=$ Grain yield in kilogram per hectare, $\mathrm{MD}=$ days to maturity, $\mathrm{PH}(\mathrm{cm})=$ plant height in centimeter, $\mathrm{NPB}=$ number of primary branch, $\mathrm{PPP}=$ pods per plant,

Table-3. Mean squares from combined analyses of variance over two years for 8 traits of Chickpea varieties grown at Abaya in 2010 and 2011 E.C

\begin{tabular}{|c|c|c|c|c|c|c|c|c|c|}
\hline $\begin{array}{l}\text { Source of } \\
\text { variation }\end{array}$ & Df & GY (t/ha) & FD & MD & $\begin{array}{l}\text { PH } \\
(\mathrm{cm})\end{array}$ & NPB & PPP & SPPnt & Spp \\
\hline Year (Y) & 1 & $\begin{array}{l}660731.049 \\
* * *\end{array}$ & $\begin{array}{l}168.894 \\
* * *\end{array}$ & $\begin{array}{l}665.004 \\
* * *\end{array}$ & $\begin{array}{l}1026.17 \\
* * *\end{array}$ & $\begin{array}{l}66.223 \\
* * *\end{array}$ & $\begin{array}{l}156.400 * \\
*\end{array}$ & $109.796 *$ & 0.0017 \\
\hline $\begin{array}{l}\text { Variety } \\
\text { (V) }\end{array}$ & 8 & $\begin{array}{l}275176.187 \\
* * *\end{array}$ & $\begin{array}{l}68.970 * \\
* *\end{array}$ & $\begin{array}{l}183.719 \\
* * *\end{array}$ & $\begin{array}{l}172.247 \\
* * *\end{array}$ & $\begin{array}{l}2.640 * \\
*\end{array}$ & $\begin{array}{l}162.655 * \\
* *\end{array}$ & $\begin{array}{l}260.067 * \\
* *\end{array}$ & $0.084 *$ \\
\hline $\begin{array}{l}\text { Reps. } \\
\text { withn(Y) }\end{array}$ & 4 & 4170.035 & 9.532 & 21.217 & 23.072 & $1.930 *$ & 12.890 & 2.070 & 0.028 \\
\hline $\mathrm{Y}^{*} \mathrm{~V}$ & 8 & $\begin{array}{l}35941.645 * \\
* *\end{array}$ & 3.164 & $\begin{array}{l}63.473 * \\
* *\end{array}$ & 14.256 & 1.346 & 6.8785 & 20.572 & 0.022 \\
\hline $\begin{array}{l}\text { Pooled } \\
\text { Error }\end{array}$ & 32 & 2068.333 & 10.251 & 8.811 & 9.535 & 0.663 & 14.684 & 20.387 & 0.036 \\
\hline $\mathrm{CV}(\%)$ & & 10.85 & 5.82 & 2.995 & 8.152 & 17.556 & 24.61 & 31.49 & 21.078 \\
\hline
\end{tabular}

$\mathrm{ns},{ }^{*}, * * \& * * *$,non-significant, significant at $\mathrm{P}<0.05, \mathrm{P}<0.01$ and $\mathrm{P}<0.001$, respectively. $\mathrm{DF}=$ degree of freedom, $\mathrm{FD}=$ days to flowering, $\mathrm{GY}(\mathrm{kg} / \mathrm{ha})=$ Grain yield in kilogram per hectare, $\mathrm{MD}=$ days to maturity, $\mathrm{PH}(\mathrm{cm})=$ plant height in centimetre, $\mathrm{NPB}=$ number of primary branch, $\mathrm{PPP}=$ pod per plant

\subsection{Combined Analysis of Variance Over Location}

Location wise analyses were performed and error variances were subjected to F-test for homogeneity of variance. Variables with homogeneous error variances were subjected to combined analysis, and as well as evaluation of varieties performance were conducted using the pooled mean values over locations. Whereas, for those traits with heterogeneous error variances, evaluation of varieties were conducted using each location mean values. Accordingly, pods per plant, seeds per plant and grain yield exhibited heterogeneous error variances and the mean squares for locations were also significant indicating the performance of the genotypes cannot be evaluated on the basis of pooled mean values over locations. However, the homogeneity of error variances for flowering date, maturity date, plant height, number of primary branches and seeds per pods were homogeneous that allowed evaluation of the genotypes on the basis of combined mean values over locations.

The ANOVA results of combined analysis over locations are presented in table 4. The result of combined analysis of variance revealed the presence of highly significant $(\mathrm{P}<0.01)$ difference among locations, varieties and varieties by environment interaction for traits suggested differences in environments and the presence of sufficient 
genetic variability for these trait that can be exploited in breeding programs. Highly significant variation for grain yield other yield related traits in chickpea were also reported by various authors $[14,15,18-20]$. The significant differences were observed between locations for all traits. This indicates that the two locations were significantly different for the performance of varieties for these traits. The significant differences between locations were reported in chickpea by Desalegn and Pichiah [19], Desai, et al. [18] and Getachew, et al. [15].

The presence of significant verities $\mathrm{x}$ location interaction (table 4) suggested that varieties had differential performance at the two locations for these traits. The differential performance of varieties across environment varies significantly and the performance of plants depends directly on the environmental conditions [21]. Other authors also reported the significant influence of genotype by location interaction on the performance of chickpea $[15,18,19]$.

Table-4. Pooled Mean squares from combined analyses of variance over two locations and two years for four traits of Chickpea varieties grown at B/Hora and Abaya in 2010 and 2011E.C

\begin{tabular}{l|l|l|l|l|l}
\hline Source of variation & DF & FD & MD & Pht & NPB \\
\hline Locations (L) & 1 & $2498.891^{* * *}$ & $5896.333^{* * *}$ & $736.333^{* * *}$ & $3.067 *$ \\
\hline Replications (L) & 4 & $21.356^{*}$ & $28.01 * *$ & 22.638 & $4.803^{* * *}$ \\
\hline Years (Y) & 1 & $368.521 * * *$ & 5.787 & $926.935^{* * *}$ & $68.800 * * *$ \\
\hline $\mathrm{L} * \mathrm{Y}$ & 1 & 0.669 & $1511.259^{* * *}$ & $220.735^{* * *}$ & $10.329 * * *$ \\
\hline Varieties ( V) & 8 & $116.214 * * *$ & $262.318^{* * *}$ & $283.613^{* * *}$ & $2.065^{* *}$ \\
\hline $\mathrm{L} * \mathrm{~V}$ & 8 & 4.787 & 15.974 & $26.647 *$ & $2.825 * * *$ \\
\hline $\mathrm{Y} * \mathrm{~V}$ & 8 & 7.219 & $50.459^{* * *}$ & 13.026 & 0.945 \\
\hline $\mathrm{L} * \mathrm{~V} * \mathrm{Y}$ & 8 & 2.315 & $18.796^{*}$ & 14.843 & $3.011^{* * *}$ \\
\hline Pooled Error & 68 & 8.143 & 8.024 & 10.806 & 0.720 \\
\hline $\mathrm{CV}$ & & 4.767 & 2.66 & 8.12 & 18.976 \\
\hline Mean & & 59.85 & 106.47 & 40.49 & 4.47 \\
\hline
\end{tabular}

$\mathrm{ns},{ }^{*}, * * \& * * *$, non-significant, significant at $\mathrm{P}<0.05, \mathrm{P}<0.01$ and $\mathrm{P}<0.001$, respectively. $\mathrm{DF}=$ degree of freedom, $\mathrm{FD}=\mathrm{days}$ to flowering, $\mathrm{L}=$ locations, $\mathrm{MD}=$ days to maturity, $\mathrm{PH}(\mathrm{cm})=$ plant height in centimeter, $\mathrm{NPB}=$ number of primary branch, $\mathrm{Rep}=$ Replications, V= Variety, Y= year

\subsection{Mean Performance of Varieties}

\subsubsection{Crop Phenology}

Flowering duration of nine varieties of chickpea ranges from 59.75-69.25 and 49.67-60.00 days at Bule hora and Abaya respectively while the maturity duration of varieties ranges from 109.00-120.67 and 90.5-106.08 days at Bule hora and Abaya respectively. The mean performances of for these traits are presented in Tables 5 and 6 . The varieties showed early flowering and maturity at Abaya than Bule hora. This might be due to the altitude and temperature differences of the two locations, where by Abaya is located at an altitude of $1442 \mathrm{~m}$. a. s. 1 . with mean minimum and maximum temperature of $12.6-29.9{ }^{\circ} \mathrm{C}$ while Bule hora is located at an altitude of $2322 \mathrm{~m}$. a. s. 1. with mean minimum and maximum temperature of $15-30{ }^{\circ} \mathrm{C}$. The pooled mean over location and year (Table 7) for flowering and maturity date ranges from 54.71-64.63 and 99.75-113.38 days respectively. The earliest maturing varieties was Dimtu (99.75 days) followed by Dalota (101.29 days) and Minjar (102.29 days) while the late maturing variety was Dhera (113.375 days) followed by Hora (110.58) and Areri (109.67) (Table 7). Four varieties exhibit lower number of days to maturity than over all mean.

\subsubsection{Growth Traits}

Mean performances of genotypes for plant height at Abaya ranged from $33.3 \mathrm{~cm}$ to $50.06 \mathrm{~cm}$ with location mean of $37.88 \mathrm{~cm}$; whereas mean performance of varieties for plant height ranged from $37.0 \mathrm{~cm}$ to $53.8 \mathrm{~cm}$ with location mean of $43.10 \mathrm{~cm}$ at Bule hora (Tables 5 and 6). The mean values of chickpea for plant height ranged from 36.18 to 51.93 with over all mean values of 40.49. Similar result for mean and range for plant height in Chick pea varieties were also reported previously by Dan, et al. [17] and Ercan, et al. [14]. Genotypes attained higher plant height at Bule hora than at Abaya.

Varieties showed considerable variations for number of primary branches that ranged from 3.23 for Ejare to 5.27 for Dalota at Bule hora (table 5); and 3.57 for Dimtu to 5.37 for 5.37 for Dhera at Abaya (table 6). The mean performance of varieties for number of primary branches were 4.60 at Abaya and 4.30 at Bule hora with pooled mean of 4.47. Six varieties recorded superior number of primary branches than the mean performance of varieties (Table 7). Existence of significant variations among Chickpea varieties for number of primary branches was also reported by Dan, et al. [17].

\subsubsection{Yield and Yield Components}

The variation of varieties for pods number per plant and seeds number per plant ranged from 23.57 to 44.97 ; and 21.6 to 52.83, respectively at Bule hora. The variation of these two traits ranged from 9.67 to 27.91 and 7.93 to 30.4 , respectively at Abaya. Minjar had significantly higher pods, seeds number per plant and seed per pod at both locations (Tables 5 and 6). The existence of considerable variations for pods number, seeds number per plant and seed per pod was also reported by other authors in Chickpea Getachew, et al. [15], Dan, et al. [17] and Ercan, et al. [14]. The mean grain yield of varieties ranged from $571.7 \mathrm{~kg}$ to $1087.5 \mathrm{~kg} ; 226.57 \mathrm{~kg}$ to $873.79 \mathrm{~kg}$ at Bule hora and Abaya, respectively (Tables 5 and 6). At Bule hora, significantly highest mean grain yield was measured from Minjar (1087.5kg/ha) followed by Natoli $(1030.94 \mathrm{~kg} / \mathrm{ha})$ and the lowest mean grain yield was obtained from Hora 
$(571.7 \mathrm{~kg} / \mathrm{ha})$ followed by Dhera $(600.35 \mathrm{~kg} / \mathrm{ha})$. At Abaya the highest grain yield was obtained from variety Minjar $(873.79 \mathrm{~kg} / \mathrm{ha})$ followed by dalota $(583.16 \mathrm{~kg} / \mathrm{ha})$ and the lowest grain yield was measured from Dhera $(160.42 \mathrm{~kg} / \mathrm{ha})$ followed by Hora $(226.57 \mathrm{~kg} / \mathrm{ha})$. Four varieties gave grain yields greater than mean grain yield of varieties at Bule hora and four varieties had grain yield greater than mean yield of varieties at Abaya as well. In all cases, Minjar is significantly well performing variety at both locations (Tables 5 and 6).

\begin{tabular}{|c|c|c|c|c|c|c|c|c|}
\hline Variety & FD & MD & PH(cm) & NPB & PPP & SPPnt & Spp & GY(kg/ha) \\
\hline Dhera & $69.250 \mathrm{a}$ & $120.667 a$ & $53.800 \mathrm{a}$ & $5.00 \mathrm{ab}$ & $34.63 b$ & $28.20 \mathrm{~b}$ & $0.850 \mathrm{~b}$ & $600.35 \mathrm{fg}$ \\
\hline Areri & $65.417 b c$ & $115.417 \mathrm{~b}$ & $37.000 \mathrm{e}$ & $4.367 a-c$ & $28.07 b c$ & $24.967 \mathrm{~b}$ & $0.867 b$ & 689.06de \\
\hline Hora & $67.333 \mathrm{ab}$ & $116.583 b$ & $42.133 b-d$ & $4.067 \mathrm{~b}-\mathrm{d}$ & $33.33 b c$ & $29.36 b$ & $0.850 \mathrm{~b}$ & $571.70 \mathrm{~g}$ \\
\hline Ejere & $65.00 \mathrm{bc}$ & $115.500 \mathrm{~b}$ & $40.667 \mathrm{c}-\mathrm{e}$ & $3.233 \mathrm{~d}$ & $23.57 \mathrm{c}$ & $21.60 \mathrm{~b}$ & $0.900 \mathrm{~b}$ & $856.15 c$ \\
\hline Habru & 59.750 & $116.333 b$ & $45.000 \mathrm{bc}$ & $4.400 \mathrm{a}-\mathrm{c}$ & $31.47 b c$ & $27.367 b$ & $0.900 \mathrm{~b}$ & 661.29ef \\
\hline Natoli & $66.083 a-c$ & $111.500 \mathrm{c}$ & $39.867 \mathrm{de}$ & $3.867 \mathrm{~cd}$ & $25.767 b c$ & $26.07 b$ & $0.967 \mathrm{ab}$ & $1030.94 \mathrm{ab}$ \\
\hline Minjar & $63.417 \mathrm{~cd}$ & $109.583 c$ & $45.900 \mathrm{~b}$ & $4.567 \mathrm{a}-\mathrm{c}$ & $44.967 \mathrm{a}$ & $52.833 a$ & $1.150 \mathrm{a}$ & $1087.50 \mathrm{a}$ \\
\hline Dalota & $64.667 b c$ & $110.167 c$ & $41.733 b-d$ & $5.267 \mathrm{a}$ & $35.40 \mathrm{ab}$ & $26.067 b$ & $0.867 \mathrm{~b}$ & $759.38 \mathrm{~d}$ \\
\hline Dimtu & $61.083 \mathrm{de}$ & $109.00 \mathrm{c}$ & $41.800 \mathrm{~b}-\mathrm{d}$ & $3.967 \mathrm{~b}-\mathrm{d}$ & $30.10 b c$ & $29.167 b$ & $0.967 \mathrm{ab}$ & $975.18 b$ \\
\hline Mean & 64.67 & 113.86 & 43.10 & 4.30 & 31.92 & 30.07 & 0.92 & 803.50 \\
\hline Range & $\begin{array}{l}59.75- \\
69.25\end{array}$ & $\begin{array}{l}109.00- \\
120.67\end{array}$ & $37.0-53.8$ & $\begin{array}{l}3.23- \\
5.27\end{array}$ & $\begin{array}{l}23.57- \\
44.97\end{array}$ & $\begin{array}{l}21.6- \\
52.83\end{array}$ & $\begin{array}{l}0.85- \\
1.15\end{array}$ & $\begin{array}{l}571.7- \\
1087.5\end{array}$ \\
\hline
\end{tabular}

Means with the same letters in the same columns are not significantly differentFD $=$ days to flowering, $\mathrm{GY}(\mathrm{kg} / \mathrm{ha})=\mathrm{Grain}$ yield in kilogram per hectare, $\mathrm{MD}=$ days to maturity, $\mathrm{PH}(\mathrm{cm})=$ plant height in centimetre, $\mathrm{NPB}=$ number of primary branch, $\mathrm{PPP}=$ pod per plant, SPPnt $=$ seed per plant, $\mathrm{Spp}=$ seed per pod

\begin{tabular}{l|l|l|l|l|l|l|l|l}
\multicolumn{6}{l}{ Table-6. Mean value of yield and yield related traits of 9 Varieties of Chickpa tested at Abaya in 2010 and 2011 E.C cropping season } \\
\hline Variety & FD & MD & PH $(\mathbf{c m})$ & NPB & PPP & SPPnt & Spp & GY $(\mathbf{k g} / \mathbf{h a})$ \\
\hline Dhera & $60.00 \mathrm{a}$ & $106.08 \mathrm{a}$ & $50.06 \mathrm{a}$ & $5.37 \mathrm{a}$ & $9.67 \mathrm{c}$ & $9.73 \mathrm{~cd}$ & $1.01 \mathrm{ab}$ & $160.42 \mathrm{~g}$ \\
\hline Areri & $57.25 \mathrm{ab}$ & $103.92 \mathrm{abc}$ & $35.37 \mathrm{~cd}$ & $5.00 \mathrm{ab}$ & $13.37 \mathrm{bc}$ & $10.50 \mathrm{~b}-\mathrm{d}$ & $0.78 \mathrm{bc}$ & $278.13 \mathrm{f}$ \\
\hline Hora & $56.750 \mathrm{ab}$ & $104.58 \mathrm{ab}$ & $37.93 \mathrm{c}$ & $5.23 \mathrm{a}$ & $11.47 \mathrm{bc}$ & $7.93 \mathrm{~d}$ & $0.72 \mathrm{c}$ & $226.57 \mathrm{f}$ \\
\hline Ejere & $53.750 \mathrm{bc}$ & $100.42 \mathrm{~cd}$ & $37.80 \mathrm{c}$ & $5.30 \mathrm{a}$ & $13.20 \mathrm{bc}$ & $11.77 \mathrm{~b}-\mathrm{d}$ & $0.90 \mathrm{a}-\mathrm{c}$ & $353.94 \mathrm{e}$ \\
\hline Habru & $49.667 \mathrm{~d}$ & $101.08 \mathrm{bcd}$ & $42.53 \mathrm{~b}$ & $4.83 \mathrm{a}-\mathrm{c}$ & $16.57 \mathrm{~b}$ & $14.50 \mathrm{bc}$ & $0.88 \mathrm{a}-\mathrm{c}$ & $388.72 \mathrm{de}$ \\
\hline Natoli & $58.75 \mathrm{a}$ & $97.75 \mathrm{de}$ & $33.30 \mathrm{~d}$ & $4.13 \mathrm{~b}-\mathrm{d}$ & $15.30 \mathrm{~b}$ & $13.23 \mathrm{~b}-\mathrm{d}$ & $0.83 \mathrm{a}-\mathrm{c}$ & $420.66 \mathrm{~d}$ \\
\hline Minjar & $53.917 \mathrm{bc}$ & $95.00 \mathrm{ef}$ & $35.17 \mathrm{~cd}$ & $4.46 \mathrm{a}-\mathrm{d}$ & $27.92 \mathrm{a}$ & $30.40 \mathrm{a}$ & $1.07 \mathrm{a}$ & $873.79 \mathrm{a}$ \\
\hline Dalota & $53.833 \mathrm{bc}$ & $92.42 \mathrm{fg}$ & $34.10 \mathrm{~cd}$ & $3.87 \mathrm{~cd}$ & $16.53 \mathrm{~b}$ & $14.67 \mathrm{bc}$ & $0.88 \mathrm{a}-\mathrm{c}$ & $583.16 \mathrm{~b}$ \\
\hline Dimtu & $51.50 \mathrm{~cd}$ & $90.50 \mathrm{~g}$ & $34.63 \mathrm{~cd}$ & $3.57 \mathrm{~d}$ & $16.10 \mathrm{~b}$ & $16.30 \mathrm{~b}$ & $1.03 \mathrm{ab}$ & $484.03 \mathrm{c}$ \\
\hline Mean & 55.046 & 99.08 & 37.88 & 4.64 & 15.568 & 14.337 & 0.90 & 418.82 \\
\hline Range & $49.667-$ & $90.5-$ & $33.3-$ & $5.37-$ & $27.91-$ & $30.4-$ & $1.07-$ & $873.79-$ \\
& 60.00 & 106.08 & 50.06 & 3.57 & 9.67 & 7.93 & 0.72 & 226.57 \\
\hline
\end{tabular}

Means with the same letters in the same columns are not significantly different

$\mathrm{FD}=$ days to flowering, $\mathrm{GY}(\mathrm{kg} / \mathrm{ha})=$ Grain yield in kilogram per hectare, $\mathrm{MD}=$ days to maturity, $\mathrm{PH}(\mathrm{cm})=$ plant height in centimetre $\mathrm{NPB}=$ number of primary branch, SPPnt $=$ seed per plant, $\mathrm{Spp}=$ seeds per pod, $\mathrm{PPP}=$ pods per plant

Table-7. Pooled Mean values of yield and yield related traits of 9 Varieties of Chickpea tested at Abaya and B/ hora in $2010 \mathrm{E} . \mathrm{C}$ and 2011 cropping season

\begin{tabular}{l|l|l|l|l}
\hline Variety & FD & MD & Pht & NPB \\
\hline Dhera & $64.63 \mathrm{a}$ & $113.375 \mathrm{a}$ & $51.933 \mathrm{a}$ & $5.183 \mathrm{a}$ \\
\hline Areri & $61.33 \mathrm{bc}$ & $109.667 \mathrm{bc}$ & $36.183 \mathrm{e}$ & $4.683 \mathrm{ab}$ \\
\hline Hora & $62.04 \mathrm{~b}$ & $110.583 \mathrm{~b}$ & $40.033 \mathrm{c}$ & $4.650 \mathrm{ab}$ \\
\hline Ejere & $59.38 \mathrm{~cd}$ & $107.958 \mathrm{c}$ & $39.233 \mathrm{~cd}$ & $4.267 \mathrm{bc}$ \\
\hline Habru & $54.71 \mathrm{e}$ & $108.708 \mathrm{bc}$ & $43.767 \mathrm{~b}$ & $4.617 \mathrm{ab}$ \\
\hline Natoli & $62.42 \mathrm{ab}$ & $104.625 \mathrm{~d}$ & $36.583 \mathrm{de}$ & $4.00 \mathrm{bc}$ \\
\hline Minjar & $58.67 \mathrm{~d}$ & $102.292 \mathrm{e}$ & $40.533 \mathrm{c}$ & $4.517 \mathrm{a}-\mathrm{c}$ \\
\hline Dalota & $59.25 \mathrm{~cd}$ & $101.292 \mathrm{ef}$ & $37.917 \mathrm{c}-\mathrm{e}$ & $4.567 \mathrm{ab}$ \\
\hline Dimtu & $56.29 \mathrm{e}$ & $99.750 \mathrm{f}$ & $38.217 \mathrm{c}-\mathrm{e}$ & $3.767 \mathrm{c}$ \\
\hline Means & 59.85 & 106.47 & 40.49 & 4.47 \\
\hline
\end{tabular}

Means with the same letters in the same columns are not significantly different

$\mathrm{FD}=$ flowering date, $\mathrm{MD}=$ Maturity date, $\mathrm{PH}=$ plant height, $\mathrm{NPB}=$ number of primary branch,

\section{Conclusions and Recommendations}

The results of this investigation showed significant variation among varieties for all traits as well as significant effect of varieties by location interaction for grain yield and most yield related traits, which indicated the differential performance of varieties across environments. The highest mean grain yield was exhibited by Minjar (1087.5kg ha1) and Natoli (1030.94kg ha-1) at Bule hora and Minjar had significantly highest mean grain yield (873.79kg ha-1) at Abaya with About four varieties gave mean grain yield greater than grand mean at Bule hora and and Abaya. Minjar variety is significantly high yielding variety at both locations with yield advantage of $26.13 \%$ and $52.07 \%$ 
over variety mean at Bule hora and Abaya respectively. The prominent chickpea varieties Minjar and Natoli are promising varieties due to their relatively higher yield and some considerable traits at Bule hora and similar agroecologies while Minjar is promising variety at Abaya. Therefore, farmers and chickpea producers around study areas and similar agro ecologies can use those varieties for chick pea production.

\section{References}

[1] Singh, K. B., 1987. "Chickpea breeding." In M.C. Saxena and K.B. Singh (eds.), The Chickpea. CAB International, UK. pp. 127-162.

[2] Redden, B. and Berger, J., 2007. "History and origin of chickpea." In Yadav SS, Redden B, Chen W, Sharma $B$ (eds) Chickpea breeding and management. CAB International, Wallingford. pp. 1-13.

[3] Van der Maesen, L. J. G., 1972. A monograph of the genus with special reference to the chickpea (Cicer arietinum L.), Its ecology and cultivation. Commun. Agric. University, Wageningen, Dordrecht, The Netherlands.

[4] Bulti, M. and Jema, H., 2019. "Economic importance of chickpea: Production, value, and world trade." Cogent Food and Agriculture., vol. 5, p. 1615718.

[5] Hulse, J. H., 1991. "Nature, composition and utilization of grain legumes." In Uses of tropical Legumes: Proceedings of a Consultants' Meeting, March 1989, ICRISAT Center. ICRISAT, Patancheru, A.P. 502 324, India. pp. 11-27.

[6] Saxena, M. C., 1990. "Problems and potential of chickpea production in nineties." In Chickpea in the nineties: proceedings of the second international workshop on chickpea improvement, 4-8 Dec 1989, ICRISAT Center, Patancheru, India.

[7] USDA, 2015. Foods Product Information Sheet, 101020. Beans: Garbanzo, Dry.

[8] Sheleme, B., Berhanu, A., Walelign, W., Endalkachew, W. M., Molla, A., Legesse, H., Wondwosen, T., Tussa, D., and Regassa, A., 2015. "Chickpea (cicer arietinum 1.) production in the southern nations, nationalities, and peoples' region of Ethiopia."

[9] Central Statistical Agency, 2017. "Federal democratic republic of ethiopia, agricultural sample survey, vol. I. Report on area and production of major crops. Private peasant holdings, in 2016/17 meher season. Statistical bulletin 584. Addis Ababa, Ethiopia."

[10] Anbessa, Y. and Bejiga, G., 2002. "Evaluation of Ethiopian chickpea landraces for tolerance to drought." Genetic Resources and Crop Evolution, vol. 49, pp. 557-564.

[11] Bejiga, G., 1994. "Forty years of research experience." In Debre Zeit Agricultural Research Center (19551994). Debrezeit, Ethiopia: Debrezeit Agricultural Research Center.

[12] Food and Agricultural Organizations of the United States Statistics, 2019. Available: http://www.fao.org/faostat/en/\#home

[13] Gomez, K. A. and Gomez, A. A., 1984. Statistical procedures for agricultural research. 2nd ed. New York, USA.: John Willey and Sons Ltd., p. 680.

[14] Ercan, C., Ali, K., and Hasan, D., 2013. "Determination of some agricultural characters of chickpea (cicer arietinum 1.) genotypes. World academy of science, engineering and technology." International Journal of Agricultural and Biosystems Engineering, vol. 7, pp. 1092-1095.

[15] Getachew, T., Firew, M., Asnake, F., and Million, E., 2015. "Genotype x environment interaction and stability analysis for yield and yield related traits of Kabuli-type Chickpea (Cicer arietinum L.) in Ethiopia." African Journal of Biotechnology, vol. 14, pp. 1564-1575.

[16] Rozina, G., Ghayour, A., Shuja, A. K., Habib, U., Khadim, S., Muhammad, I. S., Arsalan, K., Shah, H., Yousaf, K., et al., 2015. "Effect of seeds size on yield and yield components of chickpea (cicer arietinum)." Journal of Bio-Molecular Sciences, vol. 3, pp. 56-65.

[17] Dan, S. J., Kamble, M. S., Abhishek, S., and Saket, K., 2016. "Performance of chickpea (cicer arietinum 1.) genotypes in kolhapur region." International Journal of Agriculture, Environment and Biotechnology, vol. 9, pp. 283-289.

[18] Desai, K., Tank, C. J., Gami, R. A., and Patel, A. M., 2016. "G X E Interaction and stability analysis in chickpea (Cicer arietinum L.)." International Journal of Agriculture, Environment and Biotechnology, vol. 9, pp. 479-484.

[19] Desalegn, N. and Pichiah, G. N., 2019. "Genotype and environment interaction effect on yield and yield components in Desi-type Chickpea [Cicer arietinum (L.)." African Journal of Agricultural Research, vol. 14, pp. 1073-1080.

[20] Singh, K. B., Bejiga, G., and Malhotra, R. S., 1990. "Associations of some characters with seed yield in chickpea collections." Euphytica, vol. 49, pp. 83-88.

[21] Fox, P. N., B., Skovmand, B. K., Thomson, H. J., Braun, and Cormier, R., 1990. "Yield adaptation and hexaploid spring triticale." Euphytica, vol. 47, pp. 57-64. 